\title{
Editorial
}

\section{Introducing global integral constitutionalism}

J A M E T U L L Y, J E F F R E L. D U N O F F, A N T H O N F. LANG J R , M A T TIAS KU M a nd A T J E W I E N R

\section{Introduction}

As we stated in our 2012 and 2014 editorials, Global Constitutionalism is a scholarly arena of critical reflection on the contested field of global law and governance. Although there is a long history of global interaction among peoples, empires and colonies, the field was re-articulated as global and globalising after World War II and, with even more and widespread insistence, after the end of the Cold War. The field includes the law and politics of states and state-centred international law, but it situates these in the dense, global legal and governmental relationships, institutions and processes within, around and beyond the state and state-centred systems (that is, globalisation from above, in between and below).

We emphasised in our 2013 editorial that this is an inherently contested field in both practice and theory. We invited scholars from multiple disciplines to submit articles on the contested practical problems of law, governance and ethics of the field from their different methodological and normative perspectives, whether these are empirical case studies, historical interpretations, or middle- and high-level theoretical contributions. Our objective was and remains to bring to life an ongoing critical dialogue among contributors and readers around the world from their diverse perspectives. This Global Constitutionalism dialogue is not based on a pre-emptive editorial consensus or an implicit orientation towards consensus as the end point. Rather, it is an attempt to instantiate the kind of critical and problem-oriented dialogue that David Bohm, the great scientist and philosopher, argued is necessary if we are to clarify and address effectively the crises we face today. This is a form of dialogue that takes into account the fact that all perspectives are limited (perspectival) and, therefore, all disclosures of the problem and proposed solution are also limited. Thus, they always require the reciprocal enlightenment of engagement with alternative perspectives to bring each other's explicit 
claims and implicit presuppositions (limits) into the space of questions and create a genuinely multi-perspectival critical dialogue. ${ }^{1}$

The contributors to Global Constitutionalism have been remarkably successful in initiating this kind of dialogue in the journal and the events, courses and discussions that have grown around it. We look forward to its continuation and especially to contributions from perspectives that have not yet entered the arena. To facilitate this enlargement of the dialogue, in the 2015 editorial we argued that the global crises of the 'hard times' of the present call into question the globalisation of the trinity of human rights, democracy and rule of law, as well as the progressive narrative that underlies it. We suggested in response that human rights, democracy and rule of law should be seen as historically contingent and contested phenomena that should be studied contextually from a plurality of perspectives outside of the progressive framework in which they are normally situated. Furthermore, we welcomed submissions that not only critique the progressive narrative, but also the colonial and post-colonial imperial project of international law that it is said to legitimate by its critics. We would now like to take this suggestion a step further by sketching one such critical and contestable perspective and the alternative understanding of global constitutionalism that it discloses. We are not endorsing this perspective, but, rather, bringing it into the arena for critical consideration.

\section{The development paradigm and human rights, democracy and rule of law}

Global constitutionalism refers to the global field of diverse, formal and informal assemblages of laws and governance, norms and actors that exhibit constitutional qualities. Although they are contested, constitutional qualities include features such as: the distribution and separation of powers, responsibilities, rights and offices; secondary rules that constitute and limit primary rules, courts and governments; bindingness and compliance mechanisms; degrees and types of institutionalisation; intergenerational persistence; publicity, non-arbitrariness and contestedness; and widely accepted norms of legitimation. A sufficient number of such features constitute assemblages of governance and laws as 'systems'. Different systems of laws and governance around the globe exhibit various subsets of these constitutional qualities and, accordingly, are called constitutions, constitutional systems, and 'processes of constitutionalisation' to that extent.

In the modern West, constitutions and constitutional processes are standardly seen as the basic constitutional qualities or structure of a state

${ }^{1}$ D Bohm, On Dialogue (Routledge, London and New York, NY, 2014). 
and state system under international law that coordinates the domains of law, representative governance, foreign policy, economy, technology, militaryindustrial complexes, public and private, human rights, citizen participation and popular sovereignty (or constituent power). The well-known, unattained yet enduring immanent ideal of this modern form of constitutionalism is that the constitutional qualities coordinate the constituent power of the people (or peoples) and the rule of law across these domains so that they are always equally basic or equiprimordial: the people and peoples who are subject to the laws are also the ongoing authors of them, directly and/or through delegated and revocable representatives (what we call democratic constitutionalism).

Broadly speaking, the space of questions our journal seeks to open includes questions such as: what are the global assemblages of law and governance? What kinds of constitutional qualities do they exhibit? What systems of coordination or non-coordination do they bring about, and with what consequences? Do new spaces emerge where constitutional norms are negotiated by a plurality of stakeholders? And if so, what are the potentially novel organising principles that are forged through these bottomup practices of constitutionalisation? The objective is to enquire into these sorts of question without disclosing the field in terms of constitutionalisation within states, yet also to learn from the similarities and dissimilarities between state and global constitutionalisation.

In our 2012 editorial we noted that three norms of legitimation of constitutional states (human rights, democracy and rule of law) were predicated of processes of globalisation from the founding of the United Nations onward. Much of the contestation of globalisation has been devoted to struggling for their realisation in diverse practices and to critical reflection on the norms and practices of implementation from different perspectives and traditions of interpretation in academic research. Yet, much of this research, in Global Constitutionalism articles and elsewhere, shows how poorly these norms represent the real, grim and violent world of contemporary globalisation. This disconnection between the trinity and the real world of globalisation is the reason we turned in our 2015 editorial to question a fourth norm predicated of globalisation: progressive development. This norm posits a set of global processes that is presumed to bring about the necessary historical conditions for realising democracy, human rights and rule of law. This supposed relationship between a certain kind of economic and technical development and the realisation of human rights, democracy and rule of law is the 'development paradigm' we wish to examine.

From this modernising and globalising perspective, human rights, democracy and rule of law are not seen as primary or constitutive constitutional qualities, but, rather, as secondary constitutional qualities 
that are realised by the gradual spread around the globe of the more basic constitutional qualities of the development paradigm. Economic and technical development move assemblages of law, governance and forms of subjectivity through stages of development from authoritarianism to modern constitutionalisation, rule of law, social mobilisation, human rights and democratisation. In 1944 Karl Polanyi pointed out the three constitutive processes and institutions of economic constitutionalisation that drive development: the privatisation, commodification and constitutionalisation of the earth (natural resources); human productive capacities (human resources); and money (fiscal resources). That is, private law precedes and sets out the range and limits of regulatory possibilities for public law and its coordination role. ${ }^{2}$

According to the development paradigm, these three processes and institutions of commodification are placed under the control of private corporations and spread around the world and protected by military and financial competition among states during and after colonisation; by profit-driven competition among corporations; and by competition among governments, parties, unions, communities and individuals for jobs. In time and through the exercise of military and financial power, the more advanced states and corporations establish institutions of global governance and bring the weaker states in line. Once the primary constitutional qualities of economic constitutionalisation are secured by top-down institutions of global law and governance, the realisation of the secondary constitutional qualities of human rights, democracy and regulatory rule of law will follow by progressive social mobilisation, governments and civil society actors engaging in reforms or revolutions. Global constitutionalisation thus follows the same general development pattern as state constitutionalisation, yet with specific differences in stages and the much-discussed question of the institutional form of the end state (world state, plurality, hegemony, communism, unlimited growth, endless conflict, and so on).

The central dynamism of development is explained by its mobilisation of competitive freedom and the lack of any overall plan or governance, which would intervene in the private sphere, infringe on freedom, and stifle growth. Hence, establishing the historical conditions for the global realisation of human rights, democracy and rule of law, and thus global justice and perpetual peace, is the unintended consequence of self-interested competition for wealth and power of the free actors caught up in the modernising processes. Vicious means bring about virtuous ends.

2 K Polanyi, The Great Transformation: The Political and Economic Origins of Our Time, Introduction by J Stiglitz (Beacon Press, Boston, MA, 2004). See further at section IV below. 
This 'hidden-hand' development paradigm became orthodoxy in the nineteenth century. Adam Smith, Immanuel Kant, Georg W Hegel, John Stuart Mill, Karl Marx and Max Weber initiated its major schools of interpretation and legitimation. These schools have continued to dominate the interpretation, legitimation and debate of globalisation since World War II.

When critics raise doubts about this meta-narrative over the last century and in our times, its apparent setbacks and depressions are explained by uneven development or the backwardness of those who resist. Its remarkable capacity to overthrow non-compliant regimes, defeat revolutions, survive wars and crises, and continue to grow is said to be proof of its inevitability and the non-existence of any alternative modernity or globalisation. Moreover, the very idea of progressive development by means qualitatively different from its legitimating ends enables its proponents to locate its norms of legitimation in the realm of the 'to come' no matter what happens. Thus, the discontented and impatient are told to become mature, stay the course in the face of hard and seemingly contradictory times, and hold tight to the blind faith that more inequality will lead eventually to equality; war and war preparation to peace and disarmament, authoritarian rule to democracy; competition to cooperation; capitalism to communism, securitisation to liberty, emergency law to rule of law; withholding human rights to human rights; more development to creative technological climate change solutions, and so on. ${ }^{3}$

\section{Sustainability crises}

Despite these sophisticated yet circular defences of the development paradigm in response to recurrent anomalies, critical scholars and activists remain unpersuaded. They continue to raise objections and offer alternatives. ${ }^{4}$ They point to four global sustainability crises that appear to be brought

${ }^{3}$ Immanuel Kant, Universal History with a Cosmopolitan Intent and Karl Marx and Friedrich Engels, The Communist Manifesto, presented two of the most influential versions of this structure of argument that vicious means, while unjust, are necessary means to virtuous ends, despite appearances to the contrary. Mahatma Gandhi, Hind Swaraj, and Hannah Arendt, On Violence, presented two of most influential criticisms of it and alternatives to it. They both reasserted the traditional view that vicious means beget vicious ends and virtuous means beget virtuous ends.

4 The classic refutation of the development paradigm is G Rist, The History of Development: From Western Origins to Global Faith (Zed Books, London, 1997). For a careful analysis of how the unexamined faith in development continues in the contemporary normative literature on globalisation, see A Allen, The End of Progress (Columbia University Press, New York, NY, forthcoming 2016). 
about by the development paradigm and which fly in the face of its faith in progress. $^{5}$

The first crisis is the systemic, intergenerational inequalities, poverty, starvation and suffering within the Global South, and, increasingly within the Global North. The second is the expanding military-industrial-intelligence complexes engaged in escalating cycles of violence and counter-violence: war preparation, wars of massive human, infrastructural and environmental destruction, reconstruction, and rearmament. The third is the ecological crisis, including climate change and the onset of a sixth mass extinction. The fourth is the refugee and migrant crisis.

These four global crises are interconnected by the global processes that bring them about and reproduce them. The historical processes of modernisation, industrialisation, Western expansion, economic globalisation and rapid exploitation and depletion of the world's renewable and nonrenewable resources are the major cause of climate change and the ecological crisis. They are also the major cause of the inequalities between the global north and south, and within the global north and south. And, one of the primary roles of the escalating global military-industrial complexes of the great powers is to protect and expand the very processes of economic globalisation that are deeply implicated in the ecological and inequality crises. Major factors of the refugee and migrant crisis are the destabilising effects of Western imperialism, the war and arms sales complex, poverty, climate change and the ethnic and religious differences that these processes transform into armed antagonisms. These four interconnected processes generate resistances of various kinds, and the responses to the resistances in turn often generate complex positive feedback loops that amplify the inequalities, recourse to violence and counter-violence, and ecological damage, pollution and global warming. Moreover, the interactions of these far-from-equilibrium complex systems produce multiple, ramifying collateral and boomerang effects and tipping points on all life systems on earth that are difficult, if not impossible, to predict and control, as we mentioned in our 2015 editorial. ${ }^{6}$

As a result, these systemic crises are called 'sustainability and well-being' crises because their cumulative effects damage and destroy the interdependent social, ecological and atmospheric networks and cycles that co-sustain the life and well-being of Homo sapiens and millions of non-human species and ecosystems. They are damaging and destroying the ecological conditions and

5 The most comprehensive account is C Dilworth, Too Smart for Our Own Good: The Ecological Predicament of Humankind (Cambridge University Press, Cambridge, 2010). For our disagreement with the doomsaying conclusion he draws, see text accompanying $\mathrm{n} 27$ below.

6 See also LR Brown, World on the Edge: How to Prevent Environmental and Economic Collapse (WW Norton and Co, London, 2011). 
living networks that have sustained life on earth for over 3.5 billion years as the successive reports of the Intergovernmental Panel on Climate Change show. ${ }^{7}$ The evidence for this multiple crisis of sustainability and well-being was sufficient by the 1980s for a new norm to emerge and be widely accepted in principle across all systems of law and governance: sustainability and well-being. ${ }^{8}$

\section{Global economic constitutionalism}

Moreover, these four crises take place in the context of a global democratic deficit that severely constrains effective responses. When governments and citizens organise to contest, regulate and reform the unsustainable development processes they find that they are severely limited by the global economic constitution of the development paradigm in the following antidemocratic ways. The global processes of development that are the major causes of the crises are driven largely by transnational corporations (TNCs) that profit from the activities that cause them. They have grown so large on the basis of the three commodifications that they are now more powerful than most governments and citizens' movements. Governments and citizens have become dependent on them for taxes, financing, jobs and consumer lifestyles that feed the crises. TNCs have become 'shadow sovereigns'.

From the General Agreement on Tariffs and Trade (GATT) to World Trade Organisation (WTO), International Monetary Fund (IMF) and World Bank (WB) to the latest Free Trade Agreements (FTAs), such as Transatlantic Trade and Investment Partnership (TTIP) and Transpacific Trade Partnership (TTP), they put in place global systems of trade laws, agreements and treaties. These legal regimes function as the constitutional quality of 'secondary rules' relative to national constitutions, democracy, human rights and rule of law. The resulting form of global constitutionalism is often called

7 Intergovernmental Panel on Climate Change, Climate Change 2014: Fifth Assessment Synthesis Report: Longer Report (November 2014) and S Harding, Animate Earth: Science, Intuition and Gaia (Green Books, Totnes, 2013) for an analysis of the earlier reports.

8 The Club of Rome Report entitled The Limits to Growth was first published in 1972 and is recognised as one of the most influential books of the twentieth century in bringing the crisis of sustainability to the attention of the scientific community and the broader public. See also U Bardi, The Limits to Growth Revisited (Springer, New York, NY, 2011) for a survey of its influence. For a careful explication of the norm of sustainability and well-being, see A Bandarage, Sustainability and Well-Being: The Middle Path to Environment, Society and the Economy (Palgrave, London, 2013).

9 S George, Shadow Sovereigns: How Global Corporations Are Seizing Power (Polity Press, Cambridge, 2015). The following summary of economic constitutionalism draws on this study and, C Cutler, 'Legal Pluralism as the "Common Sense' of Transnational Capitalism" Oñati SocioLegal Series [online] 3(4) 719-40. Available from <http://ssrn.com/abstract=2327501>. 
neo-liberal constitutionalism or 'economic constitutionalism'. (The troika of the IMF, European Central Bank and European Commission is argued to function in a similar manner in the European Union.)

The institutions associated with global economic constitutionalism possess the authority to limit, restructure or override the authority of democratically legitimate national constitutions and rule of law. They often prescribe rules and policies that override and roll back well-established civil, social, economic and environmental rights, impose austerity programmes, and generate chronic unemployment. Similarly, their Investor to State Dispute Settlement institutions (ISDS) supplant the authority of national courts. Democratic governments, implementing the will of their citizens, can be and are sued by TNCs for millions of dollars for actions intended to advance environmental, health, safety, and other legitimate social interests. Furthermore, there is a deep asymmetry in access to the institutions of global economic constitutionalism. Only foreign investors can initiate a claim process. Thus, the narrow definition of 'stakeholder' in these institutions effectively disempowers the vast majority of citizens (and non-human life forms) that are massively affected by global economic treaties and agreements. Moreover, TNCs' well-paid lobbyists, and a handful of officially recognised non-governmental organisations, exercise non-democratic and disproportionate influence on the world's governments, institutions of global governance, and the United Nations. In these and numerous other ways, the institutions associated with global economic governance violate the basic principle of democratic legitimacy that all subject and all affected should have a say. And, finally, the secret drafting of the agreements violates the basic principles of transparency and justification. The processes that support global economic constitutionalism thus enact an anti-contestatory mode of constitutionalism.

Furthermore, the various international attempts by governments and institutions of global governance to cooperate through negotiations, treaties, protocols and accords in order to reduce poverty and social suffering, reduce war and increase disarmament, and to reduce global warming and repair destruction of ecosystems and biodiversity since the 1960s have been limited at best. These failures and limited successes are not all due to the influence of TNCs. They are also often due to denial, short-term interests trumping long-term consequences, and strategic geopolitical-economic competition among unequal states in the more familiar realist sense. However, even in these more traditional coordination problems TNCs play a significant and non-democratic role.

In these and other ways, global economic constitutionalism protects the development paradigm and TNCs from 'interference' (regulation) in the name of the primary rights of corporate persons, free trade and unlimited 
growth. In so doing, the development paradigm does not unintentionally lay the groundwork for human rights, democracy and rule of law to come, as the official narrative has it. Rather, it tends to produce and reproduce the crises of sustainability and well-being, and limit and override democratic and high-level attempts to address them. These are arguably the real unintended consequences of the development paradigm in our time. On this view, the power of the global economic constitutionalisation of the development paradigm and its crises does not begin with neo-liberalism, TNCs and the state-owned enterprises of China. They derive from the global enclosure and commodification of the last three centuries: that is, from the beginning of the Anthropocene age. ${ }^{10}$

\section{The great disembedding: Extraction and externalisation}

We can respond effectively to the four sustainability crises only if we understand how the development paradigm generates its unsustainable effects. Much of the academic literature on this points to Karl Polanyi's analysis in 1944 as among the best first-generation explanations under a sustainability and well-being framework and which more recent multidisciplinary and global research has substantiated and improved. ${ }^{11}$ Polanyi argued that during the great transformation of the last two centuries the dominant economic system has been disembedded from within the much larger ecological and social systems that sustain all life on earth and inserted in abstract and competitive economic, legal and governmental relationships that are dependent on, yet destructive of the carrying capacity of the encompassing ecological and social systems. The economic system is then treated as external and autonomous in relation to these two larger life-sustaining systems. The transformation involves four main processes.

First, indigenous peoples have been dispossessed of and removed from their life ways and ecosystems in which Homo sapiens co-evolved for 150,000 years in the name of development and progress. The genocide and destruction of indigenous peoples and their cultural systems is treated as external to the economic system imposed over their traditional territories. ${ }^{12}$

10 For a critical approach to this neoliberal global constitutionalism, see S Gill and AC Cutler (eds), New Constitutionalism and World Order (Cambridge University Press, Cambridge, 2015).

11 See Dilworth, Too Smart for Our Own Good (n 5); Bardi, The Limits to Growth Revisited (n 8); P Evans, 'Is an Alternative Globalization Possible?' (2005) 36(2) Politics and Society 271-305.

12 AJ Hall, Earth into Property: Colonization, Decolonization, and Capitalism (McGillQueen's University Press, Montreal, 2010). 
Second, the legal-economic system of privatisation and commodification of the living earth as a storehouse of 'natural resources' is imposed first in Europe then throughout the colonised world. This commodification disembeds natural resources from their place and participation in the interdependent and symbiotic ecological relationships and cycles that sustain all life on earth. It inserts them into the abstract and competitive relationships of the global market system. The damage and destruction to the surrounding, life-sustaining ecosystems caused by the extraction, production, transportation, consumption and disposal of these commodities is treated as external to the economic system.

Third, the productive capabilities of human beings are also treated as commodities for sale on the labour market by the spread of Western contract, labour and corporate law. This disembeds collective human producing and consuming capabilities and activities from the surrounding interdependent social and community relationships in which they take place. It inserts productive capacities as individual commodities (self-ownership) into abstract, competitive and non-democratic global labour market relationships. The alienation and exploitation this causes to the well-being of workers and the damage that competition does to the larger social relations in which they live are treated as externalities.

Fourth, the medium of exchange - money - is itself transformed into a commodity in the financial market. Money is disembedded from its role in fair exchange relations in which the partners are constrained to take reciprocal care of the well-being or suffering of each other as a result of the exchange. It is inserted in abstract and competitive financial exchanges in which profit maximisation is the overriding consideration. The marginalisation of gift-reciprocity or mutual-aid exchange relationships among the partners is treated as external to the financial system, leading to the financial crises and austerity programmes of the present. Polanyi predicted that the result of this great transformation would be disastrous for individuals, communities and the living earth. ${ }^{13}$

The 'fatal flaw' of this economic system is that if the costs of the repair to all the damage it does to the externalised life-support systems were 'internalised', the system would be unprofitable and would collapse. ${ }^{14}$

13 Polanyi, The Great Transformation (n 2) 97: 'To allow the market mechanism to be sole director of the fate of human beings and their natural environment ... would result in the demolition of society. Robbed of the protective covering of cultural institutions, human beings would perish from the effects of social exposure; they would die as the victims of acute social dislocation through vice, perversion, crime and starvation. Nature would be reduced to its elements, neighbourhoods and landscapes defiled, rivers polluted, military safety jeopardized, the power to produce food and raw materials destroyed.'

${ }_{14}$ Brown, World on the Edge (n 6) 8; cf. Bardi, The Limits to Growth Revisited (n 8). 
And, much of the damage is unrepairable. Moreover, it is not simply a matter of transitioning from non-renewable to renewable energy because the system exploits renewable resources at a rate that exceeds the slow temporality of the renewability cycles of renewable resources and their ecosystems (Jevons law). ${ }^{15}$ And, the race for what's left of renewable resources is as much the cause of the crises as the exploitation of nonrenewable fossil fuels and other non-renewables. ${ }^{16}$ The development paradigm becomes a super-predatory system that eventually destroys the life systems on which it depends and destroys itself. This has happened with many super-predatory species in the past, but not on this scale. ${ }^{17}$

As these features of the global development paradigm became clear in the 1970s and 1980s, from the limits to growth literature to the Gaia hypothesis, the initial response was to protect the system by grafting sustainability on to development with the elastic phrase 'sustainable development'. It became the legitimating norm under which global economic constitutionalism expanded and was unsuccessfully contested. But, as the present crises and scientific predictions substantiate, sustaining humans and the living systems that support them is incompatible with the development paradigm. If the precautionary principle were applied on the basis of the latest earth and social science predictions the economic system would have to be shut down. Hence, the choice here and now appears to be either unsustainable economic constitutionalism and much harder and catastrophic times or a sustainable alternative paradigm of economics, law and governance. ${ }^{18}$

\section{Eco-social constitutionalism}

Here is an alternative to this unsustainable global system. It is to create sustaining social systems by learning from the way life systems have sustained and diversified life on earth over 3.5 billion years. The basic principle is that successful life systems sustain themselves and their members in ways that also internalise and co-sustain the interdependent and intra-dependent life systems on which they co-depend: that is, by symbiosis and symbiogenesis.

15 R Heinberg and D Lerch (eds), The Post Carbon Reader. Managing the 21st Century's Sustainability Crises (University of California Press, Berkeley, CA, 2010).

16 M Klare, The Race for What's Left: The Global Scramble for the World's Last Resources (Picador, New York, NY, 2012).

17 Dilworth, Too Smart for Our Own Good (n 5); P Ward, The Medea Hypothesis: Is Life on Earth Ultimately Destructive? (Princeton University Press, Princeton, NJ, 2009).

18 See J Lovelock, The Rough Ride to the Future (Allen Lane, London, 2014). Lovelock sees our situation in this way but does not offer an alternative. However, his former student and co-researcher, S Harding, builds on Lovelock's work to present an alternative vision complementary to the one presented below (see Harding, Animate Earth (n 7). 
Life systems internalise their environments. Photosynthesis cycles, in which the emissions of each life form are usable or reusable by interdependent others, are the primary co-sustaining life cycles. The now widely accepted Gaia theory of James Lovelock holds that the self-sustaining features of the living earth system as a whole are themselves emergent properties of symbiosis and symbiogenesis of its member systems. Humans can learn from the way life co-sustains life. Accordingly, it is possible to learn or relearn, from the living earth and from contemporary life and earth sciences how to design sustainable social systems that co-sustain the interdependent social and ecological systems on which they reciprocally depend. This is called the great re-embedding or reconnection. ${ }^{19}$

This alternative co-sustaining, post-development paradigm already exists in what is called 'legal globalisation from below' and 'eco-social constitutionalisation'. ${ }^{20}$ It consists in practices and networks of internalising interdependency, co-sustenance and well-being of 'all affected'. These include: ecological footprint analysis of each practice, using renewable energy sources, cyclical steady-state economics rather than the linear growth economics, fair trade rather than free trade, governing the commons rather than the tragedy of privatisation and commodification, democratic cooperatives and community-based businesses rather than TNCs, communitybased and networked direct democracy as the basis of representative democracy, co-sustaining 'cradle to cradle' recycling technology and industrial planning rather than 'cradle to grave' technology of extraction, externalisation and waste, caring for common goods before private interests, non-violent means rather than violence, learning from and with indigenous peoples and their earth ways, and the application of the local and global principle that 'all affected have a say (or are stakeholders)' with respect to the exercise of any relationship of power.

In contrast to the development paradigm, in eco-social constitutionalism the means are instantiations of the ends in each of these practices: sustainability is pursued by sustainable means; peace by peaceful means; democracy by grass-roots democratic organisation: that is, the Gandhian principle of being the change. As a consequence, the modern ideal of

19 For the most comprehensive account of this view, see F Capra and PL Luisi, The Systems View of Life: A Unifying Vision (Cambridge University Press, Cambridge, 2014). The following summary draws on this synthetic work.

${ }^{20}$ For a comprehensive account of eco-social constitutionalism, see F Capra and U Mattei, The Ecology of Law: Toward a Legal System in Tune with Nature and Community (Berrett-Koehler Publishers, Oakland, CA, 2015). Compare S Bailey and U Mattei, 'Social Movements as Constituent Power: The Italian Struggles for the Commons' (2013) 20(2) Indiana Journal of Global Legal Studies 965-1013; and B de Sousa Santos and CA RodríguezGaravito (eds), Law and Globalization from Below (Cambridge University Press, Cambridge, 2005). 
coordinating constituent power and rule of law is realised to a greater degree in these practices than in our best representative institutions. ${ }^{21}$ These practitioners strive to realise human rights, democracy and rule of law, but they do so in a revolutionary way. They reinterpret and reapply these three norms not only in contextual, self-governing ways, but also under the normative framework of sustainability and well-being. Perhaps most important of all, eco-social constitutionalism, following indigenous peoples' constitutionalism, cognises natural resources, human resources and human exchanges as always already embedded within the larger lifesustaining social and ecological networks and cycles. Capra and Mattei call these 'ecolegal orders' and see them as the constitution of a new and renewed sustainable, Gaia-centric paradigm. ${ }^{22}$

This vision is hardly utopian or unachievable. There are over 800 million people engaged in these everyday practices of local and global constitutionalism from below and there is a large body of academic research on them. ${ }^{23}$ This is more people than participate in TNCs. ${ }^{24}$ Indigenous peoples and the Indigenous Peoples Working Group on Climate Change (IPWGCC) are at the heart and frontlines of this global movement. ${ }^{25}$ However, by themselves they are unable to dislodge or transform the dominant paradigm, which not only continues, but often either preys on the ecological and social repair and regrowth they generate or brings them down by the force of economic constitutionalism, austerity measures and emergency law.

\section{Contestatory constitutionalism}

If the participants of eco-social constitutionalism wish to transform the development paradigm, they need to find ways to join hands with those who are striving to contest, reform and transform it from within its economic, legal and governance institutions and processes. Many of the articles in Global Constitutionalism have been excellent case studies of

21 Bailey and Mattei, 'Social Movements as Constituent Power' (n 20).

22 Capra and Mattei, The Ecology of Law (n 20). See also B de Sousa Santos, Epistemologies of the South: Justice against Epistemicide (Routledge, London, 2014).

23 P Hawken, Blessed Unrest: How the Largest Movement in the World Came into Being and Why No One Saw It Coming (Viking, New York, NY, 2007).

${ }^{24} \mathrm{~J}$ Restakis, Humanizing the Economy: Co-operatives in the Age of Capital (New Society Publishers, Gabriola Island, 2010).

25 Z Grossman (ed), Asserting Native Resilience: Pacific Rim Indigenous Nations Face the Climate Crisis (Oregon State University Press, Portland, OR, 2012). For an example of the indigenous philosophies that underlie indigenous constitutionalism, see ER Atleo (Umeek), Tsawalk: A Nuu-chah-nulth Worldview (UBC Press, Vancouver, 2004). 
individual and collective actors engaged in diverse forms of contestation of the development paradigm and economic constitutionalisation by exercising formal human rights, representative democracy and rule of law available to them in innovative ways. We call these activities agonistic or 'contestatory global constitutionalism', using contestation in a broad sense. ${ }^{26}$ As we have suggested above, while contestatory actors have been able to regulate and reform economic constitutionalism to a limited extent, they have been unable to slow down its rapid pace, let alone transform it.

However, if practitioners of eco-social and contestatory constitutionalism were to find ways to network and coordinate their activities, they just might be able to build up an alternative world with the exemplarity, momentum and non-violent means to transform unsustainable constitutionalisation and its development paradigm, thereby proving the doomsayers wrong. ${ }^{27}$ There are good reasons why the two types of citizen engagement - often call 'horizontality' (power-with organisation) and 'verticality' (power-over organisation) - should join hands. They both share the same constitutional norms of sustainability and well-being and the all-affected principle in conjunction with human rights, democracy and rule of law, yet enact them differently. Eco-social citizens put into practice what contestatory citizens argue for in public spheres, courts, representative institutions and institutions of global governance. Reciprocally, the gains that contestatory actors make in official institutions protect and support the fragile practices of eco-social actors. Many of their activities overlap in practice; for example, when community-based organisations find it necessary to go to court or elect supportive representatives. Moreover, most citizens responding to the four crises are engaged in practices of both contestatory and eco-social constitutionalism in their daily lives, so the grounds of their coordination and integration already exist.

Yet, these two modes of constitutionalism often are seen as either working separately or eco-social organisations are subordinated to social movements oriented to gaining power in the official vertical institutions by elections or revolutions. Nevertheless, as Boaventura de Sousa Santos was among the first to point out, there are several contemporary attempts to coordinate the two modes of constitutionalism democratically and without subordination so that they are co-sustaining and co-empowering. Wellknown examples exist in Spain, Italy, India, and between indigenous peoples

26 A Wiener, A Theory of Contestation (Springer, New York, NY, 2014)

27 The doomsayers who predict the self-destruction of the majority of the world's population due to the three crises standardly overlook socio-ecological and contestatory constitutionalism. See, for example, Dilworth, Too Smart for Our Own Good (n 5); Ward, The Medea Hypothesis (n 17); S Emmott, Ten Billion (Penguin, New York, NY, 2014). 
and the government of Bolivia. Participants learn from their successes and failures, and from globally connected academic research and discussions with them and many other examples, and move forward in networks of reciprocal elucidation. ${ }^{28}$

\section{Conclusion: Integral constitutionalism}

In the Encyclical on Climate Change and Inequality, Pope Francis calls the general kind of coordinated thinking and acting together of socio-ecological and contestatory constitutionalism to care for our common home - our communities and the living earth - 'integral ecology'. ${ }^{29}$ The specific version we have put forward thus could be called integral constitutionalism. ${ }^{30}$ As we mentioned in the Introduction, a central role of Global Constitutionalism is to disclose and discuss the emergence of constitutional qualities that coordinate law and governance in different ways in the global field. The perspective we have briefly introduced brings to light three distinctive types of global constitutionalism and the important challenge of coordinating two of them into an integral constitutionalism. We are pleased to bring it into the Global Constitutionalism arena, invite critical discussion of it, and thereby partake in the larger discussion already underway.

28 For an in-depth study of the relation between socio-ecological constitutionalism (15M) and contestatory constitutionalism (Podemos) and the dilemma of non-subordination in Spain see P Ouziel, Vamos Lentos Porque Vamos Lejos: Towards a Dialogical Understanding of Spain's 15M (PhD Dissertation, University of Victoria, British Columbia, 2015). For Italy, see Bailey and Mattei, 'Social Movements as Constituent Power' (n 20). For India, see V Shiva, Earth Democracy: Justice, Sustainability and Peace (South End Press, Cambridge, 2005). For Bolivia, see Grossman, Asserting Native Resilience (n 25) and E Sahle, 'Spaces of Freedom, Citizenship and State in the Context of Globalization: South Africa and Bolivia' in R Nichols and J Singh (eds), Freedom and Democracy in an Imperial Context (Routledge, London, 2014) 147-74.

29 Pope Francis, Encyclical on Climate Change and Inequality: On Care for Our Common Home (Melville House, London, 2015).

${ }^{30}$ For critical discussion of aspects of integral constitutionalism, see R Nichols and J Singh (eds), Freedom and Democracy in an Imperial Context (Routledge, London, 2014) and J Tully, On Global Citizenship: James Tully in Dialogue (Bloomsbury, London, 2014). 